\title{
The Public Policy Implications of the Persistence of a Monopoly Versus a Duopolistic Market
}

\author{
Ahmet Özçam* \\ Yeditepe University
}

\begin{abstract}
In this paper, the welfare implications of a market environment where a new technology which reduces the cost of production that can be exploited by a preempting monopolist which obtains a patent or allows a potential entrant to share the market are investigated from a public policy point of view. The well known efficiency effect indicates that the private incentives of the monopolist are greater than those of a new entrant. However, since the consumers' benefits are higher under the two-firm market structure compared to those under the pure monopolist situation, it was interesting to examine the overall welfare results further. In neither of these two market structures was the welfare of the society found to be uniformly superior to the other. Therefore, the implications for government regulation are to allow the monopolist to reign if it introduces a significant technological cost reduction, and to promote the competition if the new cost-saving technology is small. An example from Turkey is given where in 2007 Royal Dutch Shell won a tender and acquired a portion of piped gas distribution from a giant Turkish formerly monopolist state company.
\end{abstract}

Keywords: persistence of monopoly; duopoly; cost reducing new technology; consumers' surplus, welfare.

JEL classification: D04; D43; D60.

\section{Piyasa Hakimiyetini Devam Ettirebilecek Tekele Karşı Düopol Piyasa Yapıları Durumlarında Uygulanması Gereken Devlet Politikaları}

\section{Özet}

Bu çalışmada, üretim maliyetini azaltıcı yeni bir teknolojinin patentine başkalarından önce davranarak sahip olan ve istismar gücünü kullanan mevcut bir tekel ile piyasaya potansiyel ikinci bir firmanın girmesine izin veren bir tekelci piyasa ortamlarında sosyal refah neticeleri devlet politikaları açısından incelenmiştir. İyi bilinmektedir ki verimlilik etkisi mevcut tekelin özel dürtüsü piyasaya girebilecek yeni firmanınkinden daha fazladır. Ancak, tüketici fazlası düopol piyasa şeklinde tekel durumuna göre daha çok olduğu göz önünde bulundurulursa, genel sosyal refah neticelerinin biraz daha fazla araştırılmasının ilgi çekeceği düşünülmüştür. Bu iki piyasa şeklinin hiç birinde sosyal refah neticelerinin diğer piyasa şekline mukayeseyle yeknesak bir şekilde üstün olmadığı bulunmuştur. Dolayısıyla, düzenleyici devlet açısından tekelcinin piyasada

\footnotetext{
* Ahmet Özçam is an Associate Professor in the Department of Economics at Yeditepe University, İnönü Mahallesi, Kayışdağ Caddesi, 26 Ağustos Yerleşkesi, 34755, Kadıköy, Istanbul, Turkey. E-mail. aozcam@yeditepe.edu.tr
} 
hakimiyetini sürdürmesine ancak kayda değer bir teknolojik maliyet azalması sağladığında izin verilmeli ve aksi durumda ikinci bir firmanın piyasaya girerek rekabet yapması sağlanmalıdır. Örnek olarak, Türkiye'de 2007 senesinde Royal Dutch Shell firması doğal gaz dağıtımının bir kısmına sahip olmak için açılan bir ihaleyi daha önce bu piyasada tekel konumundaki devlet firmasına karşı kazanmıştır.

Anahtar kelimeler: piyasa hakimiyetini devam ettiren tekelci, düopol, maliyet azaltan yeni teknoloji, tüketici fazlast, refah.

$\mathrm{T}$

There has long been a supposition that there is underinvestment in R\&D (Research and Development) both under competition and monopoly: this supposition is based partly on the fact that the returns from $\mathrm{R} \& \mathrm{D}$ have the features of a public good. It is also based partly on a pioneering work by Arrow (1962) who explored the gain to the successful process innovator who is the only one to undertake R \& D designed to reduce cost of production, given that its innovation in a new technology is protected by a patent of infinite duration under three forms of market structure (Dasgupta and Stiglitz, 1980a). Arrow specified the first to be the socially managed market which set the product price equal to the cost of production. The second and the third were the pure monopolist (i.e. where there are barriers to entry) and the competitive economy respectively. He concluded that the pure incentive to invent was less under monopolistic than under competitive conditions, but even in the latter case it would be less than socially desirable (Arrow, 1962). ${ }^{[1]}$ Pure incentive he saw as how much the firm would be willing to pay to obtain new technology given that no one else will buy it, which therefore was ignoring strategic moves. The replacement effect, a property due to Arrow, explained why the incentive to invent (the propensity to spend on R \& D) of the monopolist which would replace itself by increasing its initial profits was less than that of a competitive firm, and therefore the monopolist would tend to "rest on his laurels" (Tirole, 2000). The monopolist was then able to acquire only the additional amounts of profits, whereas the competitive firm starting from zero profits obtained the full amount of profits as soon as it became monopolist due to the acquisition of the patent which preempted other competitors.

Furthermore, Tirole $(2000: 392,415)$ argued that the private incentives to undertake $\mathrm{R} \& \mathrm{D}$ (without taking changes in consumers' surpluses into account) in the cases of monopoly and competitive markets, calculated in Arrow's market situations were not appropriate if, say, we wish to consider the social effectiveness of subsidizing research (social incentives). He found that the increase in welfare brought about by a big nondrastic innovation exploited by the monopolist was actually greater than that under the competitive firm, once the well-being of the consumers in each case was taken into account. ${ }^{[2]}$ However, he computed the opposite to be true for small non-drastic ones.

\footnotetext{
[1] This result can be proved using the envelope theorem in mathematics (Arrow, 1962; Tirole, 2000: 391; Varian, 1978: 267).

[2] A non-drastic innovation is a decrease in the cost of production due to the new technology if the price determined by the monopolist is higher than the initial cost of production. If on the other hand the price is less than the initial cost, other firms produce nothing, and the innovation is said to be drastic.
} 
Therefore, it could be argued that as far as the social incentives to subsidize a research were concerned, the right market structure depended on how significant (drastic) the innovation was. It is important to note that in Arrow's market situations, the innovating firms (pure monopolist or competitive firm becoming monopolist) eventually supply the entire market and the firms' incentives are evaluated with respect to their own initial positions (without the innovation or patent). However, other situations (discussed below) can be visualized where the structure of the market may depend on firms' strategic moves, and the firms may compete with differentiated cost structures in the same market.

Hence, some other situations may be relevant where the Arrow's conclusion and Tirole's extension can be discussed further. For example, a fourth market environment could exist if a monopolist was threatened by a potential entrant (challenger) and both firms would have incentives to acquire the new technology (Gilbert and Newberry, 1982). A third firm, which could not produce in this output market might be assumed to generate the innovation and to put it up for bidding between these two firms, or the two firms might compete to discover the new technology first by spending on $\mathrm{R} \& \mathrm{D}$ and getting involved in a race for a patent. In this context where the strategic moves are important, the value of the innovation is slightly different from what Arrow had assumed, since the monopolist must now consider not only the benefits of the innovation, but also what its profits will be if it does not take up the innovation but the challenger does. However, the value of the innovation is unaffected from the challenger's point of view, since it does not make any profits to begin with. Then the question arises as to whether institutions such as the patent system create opportunities for firms with monopoly power to maintain their monopoly power. In this new setting of the problem where the monopolist has the option of patenting the new technology or permitting entry to occur, Gilbert and Newberry (1982) find that the incentives of the monopolist to obtain the patent are higher than those of a challenger because competition reduces profits, and hence the monopolist would spend more on R\&D than rival firms to remain a monopolist, and preemption is the Nash equilibrium outcome in the bidding game. This result rests on the efficiency effect which states that it is reasonable to assume a monopolist will make at least as much profit as two non-colluding duopolists, or the entry will result in a reduction of total profits below the joint-maximizing level. A very good applied example given by Gilbert and Newberry where this fourth market situation was encountered is the antitrust case in which the SCM Corporation sought more than $\$ 500$ million in damages on its claim that the Xerox Corporation preserved an anticompetitive (preemptive) behavior where some inventions were used while others were neither employed nor licensed to others (the latter referred to as patent shelving or sleeping patents). Therefore, in order to avert the competition from the challenger, the monopolist may want to obtain property rights on an innovation even in the case where he does not plan to use it. For example when the new technology is not superior to that of the monopolist's existing one, or when a product innovation is not sufficiently different from the monopolist's product to necessitate its spending on the costs of introducing the new product (Tirole, 2000). Thus, the efficiency effect may be an explanation for the preemptive attitude of the monopolist in these types of inventions and may justify why an industry might tend to stay monopolized in the hands of the current incumbent. 
Of course, the efficiency effect is not contradictory to Arrow's remark that the incentive to invest in R\&D is less under monopoly than that under competition, and that the monopolist is less inclined to innovate, since Arrow had assumed that the entry was blocked in the case of monopoly with or without patent protection. Therefore, Arrow's pure monopolist evaluated the value of the innovation with respect to its own initial level of profits given by the replacement effect rather than the efficiency effect which considers the worthiness of the innovation in terms of the monopolist's profits level when the entrant obtains the patent and the market is shared by two firms.

In this paper, the fourth market environment described above where the monopolist may preempt by lowering returns to a potential competitor or allow the challenger to share the market will be investigated further. However, we will look from a different perspective, and compare the total welfare results which include the consumers' surpluses in addition to the profits of these two firms in monopolistic and duopolistic market situations. On the one hand, in view of the presence of the innovating entrant, we know that the private incentives of the monopolist are higher compared to those of the new entrant because the total market profits with two firms are necessarily below those of the jointly profit maximized level as explained by the efficiency effect. This of course reinforces the Schumpeterian argument that the incentives for technological change and product innovation comes from the prospects for above-normal, or monopoly profits, and these prospects are greater when there is monopoly power, and not when competitive conditions prevail. Schumpeter (1947) further contended that it was a fault to rest the theory of government regulation of industry on the principle that big industries should be made to work as in competitive market. The antitrust laws to impose such a competitive market would only be a cause of loss in efficiency due to a decrease in economies of scale and product innovation. On the other hand, it is certain that the consumers' surplus increases when the product price decreases in the case of entry to market. Taking both firms' profits and consumers' surpluses into account, we must always have a higher social welfare under more competition than less of it, as is explained by the classical deadweight loss notion due to underproduction and overpricing of the monopolist. However, in this paper in this particular market situation where the former monopolist has to operate with the old technology when the challenger acquires the patent, the welfare results are found to depend on the cost of the new technology, i.e. whether the non-drastic innovation is small or big. This extra factor is shown geometrically in Figure 1 and explained in the section on efficiency effect. In this paper none of these two market structures are determined to be uniformly superior to the other from a government regulation perspective. Hence, the implications for government regulation are to allow the monopolist to reign if it introduces a significant technological cost reduction, and to promote the competition if the new cost-saving technology is small.

As a recent practical example for our model, Turkey has witnessed a rapid increase in natural gas consumption for household, agriculture and electricity usage due to its relatively rapid economic growth. By 2010, 66 cities had already enjoyed piped gas distribution. In April 2007, Royal Dutch Shell Company won a tender that made it the first company to take over some of the distribution of Turkey's imported natural gas 
from the monopolist state company Botaş. The latter which had had contracts to import 25 billion cubic meters (bcm) of gas from Russia, Iran, Algeria and Nigeria annually, then had to transfer $16 \mathrm{bcm}$ of these contracts to Shell. The Russian and Turkish antitrust agencies approved the transfer of the import contracts. Some fringe competitive firms like Bosphorus Gaz, which includes Gazprom (Russian state gas company), and Enerko and Avrasya tried to capture the remaining portion of the newly formed oligopolistic gas distribution market. At that time, the decision to break up the giant Turkish state company Botaş was triggered mainly by a new law on market liberalization which obliged Botaş to cut its monopolistic ownership of gas contracts to below $20 \%$ of national consumption by the end of 2009, rather than by considerations involving the general economic welfare of Turkish and foreign producers (distributers of gas) and Turkish consumers. Our analysis in this paper indicates that this very important political/economic decision in 2007 was made properly from a microeconomic perspective, if the costs advantage of distribution of gas of the multinational Shell due to its international technology/ experience was sufficiently superior compared to the existing monopolist Turkish state company Botaş. Otherwise the law which seems to have considered the privatization as a priority, and forced Botaş to abandon its rights of distribution of natural gas does not seem to have served the overall general economic well-being of either oligopolistic distributors or Turkish consumers.

In the next section, the welfare functions are derived in monopolistic and duopolistic

market situations. The section following that discusses the efficiency effect geometrically. Then the welfare functions are compared, and the regions where each of these two types of market structures is superior are found analytically. The last section concludes that the policy implications must favor the monopolist if the cost-saving new technology is significant, or promote the competition if it is small.

\section{Economic Welfare In Monopolistic And Duopolistic Market Structures}

Let us consider the fourth case above of two firms competing for the acquisition of a patent on a new cost-reducing technology given by Gilbert and Newberry. Firm 1 is a monopolist which produces the commodity with a current best-practice technique whose initial constant marginal cost is $c$, and is already earning revenues $R$ per period. The monopolist is under the threat of entry of firm 2 (challenger) which might innovate and therefore reduce the former monopolist's (incumbent's) profits.

The market demand curve is given by

$$
P=a-b Q
$$

where $P$ and $Q$ are the market price and quantity, and $a$ and $b$ are some positive constants. The social benefits under monopolistic and duopolistic market structures will be derived analytically in subsections on "The Monopolist" and "The Duopolist" below, similar to the approach adopted by Reinganum (1983). 


\section{The Monopolist}

If the monopolist innovates and receives a patent on the new technology precluding other potential firms from entry, with $c$ being the marginal cost of the new technology, the quantity of output and price of the profit maximizing monopolist are

$$
q_{m}=(a-c) / 2 b \text { and } P_{m}=(a+c) / 2
$$

respectively and the monopolist's profits are

$$
\Pi_{m}(c)=(a-c)^{2} / 4 b \quad\left(\Pi_{m}(c)=\mathrm{A} 1+\mathrm{A} 2+\mathrm{A} 3+\mathrm{A} 4\right)
$$

where A1, A2, A3 and A4 are areas of some rectangles in Figure 1 when $a=10$, $b=1$ and $c=6.5<c=7$. The consumers' surplus under the monopolist is given by area A7 in the same Figure, which is

$$
C S_{m}=\int_{(a+c) / 2}^{a}(a-P) / b \mathrm{~d} P=(a-c)^{2} / 8 b \quad\left(C S_{m}=\mathrm{A} 7\right)
$$

Taking both the monopolist's profits and the consumers' surplus into account, the overall welfare in the monopolistic market structure is equal to the sum of these five areas in Figure 1.

$$
W_{m}=\Pi_{m}(c)+C S_{m}=3(a-c)^{2} / 8 b \quad\left(W_{m}=\mathrm{A} 1+\mathrm{A} 2+\mathrm{A} 3+\mathrm{A} 4+\mathrm{A} 7\right)
$$

Figure 1

\section{Market Outcomes Under the Monopoly and the Duopoly}

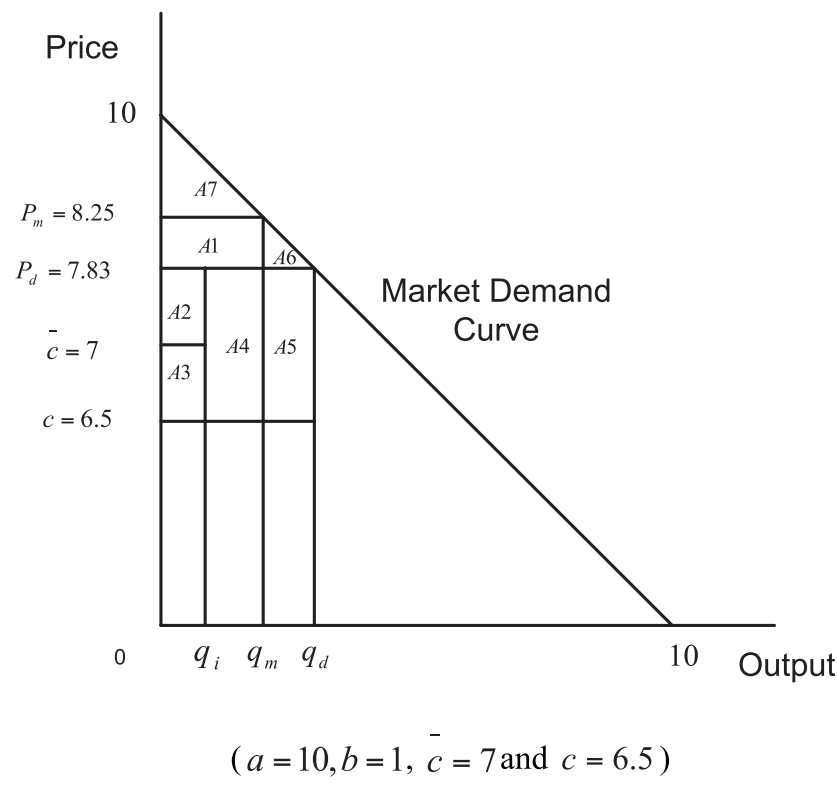




\section{The Duopoly}

On the other hand, if the challenger innovates and receives a patent on the new technology, the former monopolist (incumbent) must now continue its production with the higher marginal cost $c .{ }^{[3]}$ The incumbent maximizes its profits, behaving in a noncooperative Nash-Cournot fashion (taking the output level of the challenger as given)

$$
\operatorname{Max}_{q_{i}} \Pi_{i}(c)=P q_{i}-\bar{c} q_{i}=\left(a-b\left(q_{i}+q_{c}\right)-\bar{c}\right)^{*} q_{i}
$$

where $q_{i}, q_{c}$ and $c$ are the outputs of the incumbent, of the challenger and the marginal cost of the new technology respectively. The solution to equation (6) defines the reaction function of the incumbent for given outputs of the challenger (innovative entrant)

$$
q_{i}=\left(a-c-b q_{c}\right) / 2 b
$$

The reaction function of the challenger is similar except for the marginal cost,

$$
q_{c}=\left(a-c-b q_{i}\right) / 2 b
$$

We can obtain the equilibrium outputs of the two firms when the equations (7) and (8) are solved simultaneously.

$$
q_{i}=(a+c-2 \bar{c}) / 3 b \text { and } q_{c}=(a+\bar{c}-2 c) / 3 b
$$

It remains to calculate the profits of firms and the consumers' surplus under the duopoly with cost differences to show the total welfare under the duopoly. The profits of the incumbent which is the maximum value of equation (6) are

$$
\Pi_{i}(c)=((a-(2 a-c-\bar{c}) / 3)-\bar{c}) *((a+c-2 \bar{c}) / 3 b)=(a+c-2 \bar{c})^{2} / 9 b
$$

noting that $q_{i}+q_{c}=(2 a-c-\bar{c}) / 3 b$ is the total industry output in the duopolistic market, which is shown as $q_{d}$ in Figure 1, along with the duopolistic price, $P_{d}=(a+c+c) / 3$. Similarly, the profits of the challenger are

$$
\Pi_{c}(c)=(a-2 c+\bar{c})^{2} / 9 b
$$

Next, we calculate the consumers' surplus under the duopolistic market structure

$$
C S_{d}=\int_{(a+c+c) / 3}(a-P) / b \mathrm{~d} P=\left((c+\bar{c})^{2}+4 a(a-c-\bar{c})\right) / 18 b
$$

Finally we must add the profits of the incumbent $\Pi_{i}(c)=\mathrm{A} 2$ (eq. 10), those of the challenger $\Pi_{c}(c)=\mathrm{A} 4+\mathrm{A} 5$ (eq. 11), and the consumers' surplus $C S_{d}=\mathrm{A} 1+\mathrm{A} 6+\mathrm{A} 7$ (eq. 12) to obtain the overall welfare gain under the duopoly

$$
\begin{aligned}
& W_{d}=\Pi_{i}(c)+\Pi_{c}(c)+C S_{d}=\left(8 a(a-\bar{c}-c)+11\left(c^{2}+\bar{c}\right)-14 c \bar{c}\right) / 18 b \\
& \left(W_{d}=\mathrm{A} 1+\mathrm{A} 2+\mathrm{A} 4+\mathrm{A} 5+\mathrm{A} 6+\mathrm{A} 7\right)
\end{aligned}
$$

Next we will discuss geometrically the meaning of efficiency effect, which will be quite important in comparing the social welfare results under monopolistic and duopolistic market structures explained later in the following section.

${ }^{[3]}$ If the innovation is drastic $\left(P_{d}<c=7\right)$ such that the incumbent's optimal output level is non-positive using the old technology, then the challenger becomes monopolist. 


\section{The Geometric Representation of the Efficiency Effect}

Gilbert and Newberry showed mathematically that the monopolist would have higher incentives to obtain the patent than would the rival firms since entry would typically result in a reduction of total profits $\Pi_{i}(c)+\Pi_{c}(c)$ below the joint-maximizing or cooperating level $\Pi_{m}(c)$, which is the Efficiency Effect (EE) discussed above. Here, we will give a geometric representation of it.

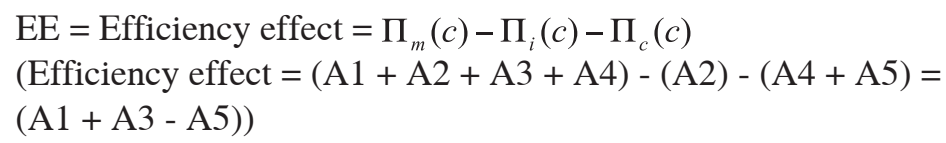

which can be seen as A1 + A3 - A5 in Figure 1. We notice that A1 - A5 portion of the efficiency effect (in eq. 14) must always be positive since this represents a movement from the initial profit-maximizing price of the former monopolist (incumbent) $P_{m}=8.25$ to a lower price level $P_{d}=7.83$ when the market is shared by two firms. This must be true since increasing output beyond $q_{m}$ where the marginal revenue of the incumbent is equal to its marginal cost can only reduce the two firm's joint profits. Therefore, it is true that the efficiency effect will be positive in the case when the total market profits start dissipating and drop below those of the joint profit maximizing level when the entrant innovates, which is given as A1 - A5 > 0. However, it is also important to recognize that in this case the incumbent is forced to continue to produce with the higher cost old technology. This extra factor which is an integral part of the efficiency effect is seen as A3 in Figure 1. Using this Figure we note that this additional factor reinforces why the monopolist may preserve an anticompetitive behavior where some of its inventions might be used while others might be neither employed nor licensed to others.

This extra factor represented as the area A3 in Figure 1 is also important in comparing the social welfare results under monopolistic and duopolistic market structures explained in the section below.

\section{The Welfare Gains Under the Monopoly and the Duopoly}

In this section we will compare the welfare functions under monopolistic and duopolistic market structures. On the one hand, in view of the presence of the innovating entrant, we know that the private incentives of the monopolist are higher compared to those of the new entrant because the total market profits with two firms are necessarily below those of the jointly profit maximized level explained by the efficiency effect. However, on the other hand, it is certain that the consumers' surplus increases when the product price decreases in the case of competition among firms. The classical deadweight loss notion always indicates a higher benefit to society under more competition than less, when both firms' profits and consumers' surpluses are taken into account. However, in this particular market situation where the former monopolist becomes obliged to operate with the old technology when the challenger acquires the patent (the additional factor A3 of the previous section) the welfare results are found to depend on the cost of the new technology, i.e. whether the non-drastic innovation is small or big. 
The positive efficiency effect (EE) is shown as the difference between the monopoly profits $\Pi_{m}(c)$ and those of the duopolistic market structure, $\Pi_{i}(c)+\Pi_{c}(c)$ in Figure 2. In the same Figure, the consumers' surplus under the duopoly, $C S_{d}$ is found to be uniformly superior to that under the monopoly $C S_{m}$ for all relevant values of cost of production $(4<c<c=7)$.

Figure 2

\section{Welfare Calculations Under the Monopoly and the Duopoly}

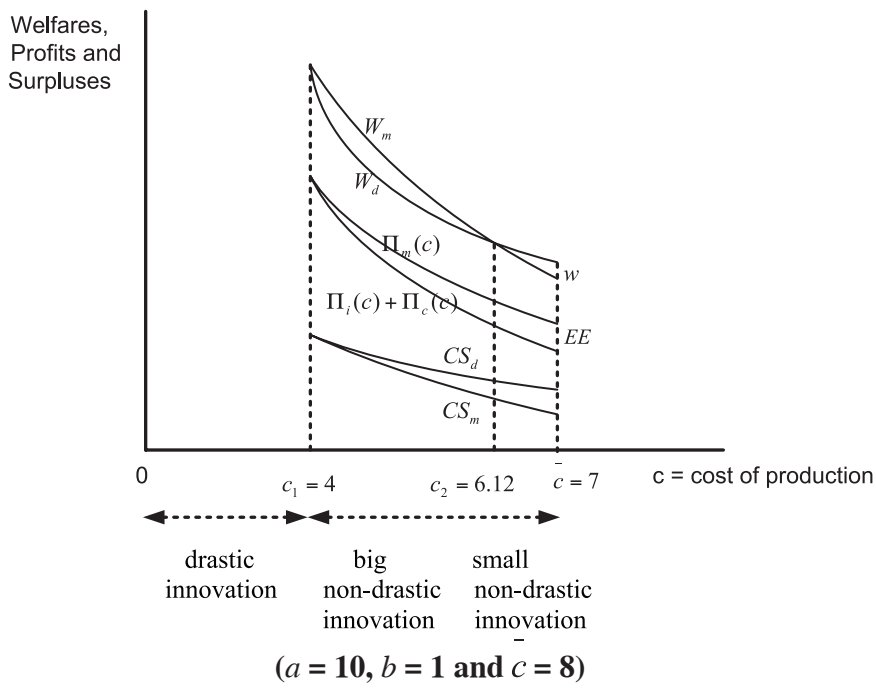

Therefore, an important question arises as to how the welfare under the monopoly, $W_{m}$ compares to that under the duopoly, $W_{d}$ taking into account both the producers' profits and the consumers' surpluses. As shown in the same Figure, the welfare results are found to depend on the cost of the new technology. In particular, the social welfare under the duopoly is superior (inferior) to that under the monopoly if the cost of the new technology is greater (smaller) than a critical value of the new technology, $c_{2}$ calculated below.

This relationship between the total welfares under the monopoly and the duopoly can also be displayed using Figure 1 where $c$ is equal to 6.5. Comparing the welfare under the monopoly, $W_{m}$ given in equation (5) with that under the duopoly, $W_{d}$ given in equation (13), the welfare advantage of the society in the case of the monopoly compared to a duopolistic market structure $(w)$ is ${ }^{[4]}$

$w=W_{m}-W_{d}$ (Welfare advantage of the monopolistic market over the duopoly)

$$
\begin{aligned}
& =(\mathrm{A} 1+\mathrm{A} 2+\mathrm{A} 3+\mathrm{A} 4+\mathrm{A} 7)-(\mathrm{A} 1+\mathrm{A} 2+\mathrm{A} 4+\mathrm{A} 5+\mathrm{A} 6+\mathrm{A} 7) \\
& =\mathrm{A} 3-\mathrm{A} 5-\mathrm{A} 6
\end{aligned}
$$

[4] In Figure-2, we notice that the society is better off when the cost of new technology is lower, since both $W_{m}$ and $W_{d}$ are decreasing functions of $c$. 
A1 and A2 + A4 are the consumers' surplus and the producers' profits transfers respectively from a movement from the monopolistic market to the duopoly as shown in Figure 1 and cancel out during the calculations of social welfare, since one side of the market is made better off at the expense of the other side being made worse off, keeping the overall well-being constant. The area $w=\mathrm{A} 3-\mathrm{A} 5$ - A6 represents the true difference in the social welfare and gives a measure of how well off all parties are paying the monopolist's price rather than paying that of the duopolistic market. ${ }^{[5]}$ Consequently, the total welfare under the monopoly is higher than that under the duopoly. This means that the former monopolist's cost advantage on the new technology when the patent were acquired by himself A3, exceeds the extra profits A5 and consumers' surplus A6 obtained for the additional units of output produced under the two-firm scheme. Conversely, if the additional social benefits (A5 + A6) of the two-firm market structure are higher than the loss in cost disadvantage of the incumbent (A3), then a duopolistic market construction is preferred from a public policy point of view. Hence, the welfare comparison of these two market structures boils down to linking the monopolist's economic cost disadvantage if the challenger innovates to the additional social benefits of the duopolistic market structure which supplies additional units of the product to the market. Thus it creates extra profits and consumers' surplus. This comparison (eq. 15) is shown as the difference $w$ between $W_{m}$ and $W_{d}$ for various new technology cost levels in Figure 2 with $a=10, b=1$ and $\bar{c}=7$. We continue by calculating analytically the new technology cost level $c$, at which these two welfare values are equal.

$$
\begin{aligned}
& w=0 \quad \rightarrow \quad \mathrm{A} 3=\mathrm{A} 5+\mathrm{A} 6 \\
& q_{i} *(\bar{c}-c)=\left(q_{d}-q_{m}\right) *\left(p_{d}-c\right)+\int_{p_{d}}^{p_{m}}\left(Q(P)-q_{m}\right) \mathrm{dP} \\
& (a+c-2 c) / 3 b *(c-c)=((2 a-c-c) / 3 b-(a-c) / 2 b) *((a+c+c) / 3-c)+ \\
& (a+c) / 2 \\
& \int_{(a+c+c) / 3}(a-P) / b-(a-c) / 2 b \mathrm{~d} P \\
& ((a+c-2 \bar{c}) / 3 b) *(5 \bar{c}-4 c-a) / 6)=\int_{(a+c+c) / 3}^{(a+c) / 2}(a+c) / 2 b-P / b \\
& (a+c-2 \bar{c}) *(5 \bar{c}-4 c-a) / 18 b=\left((a+c)^{2}-4 \bar{c}(a+c-\bar{c})\right) / 72 b
\end{aligned}
$$

The equation (19) gives rise to a polynomial of degree two in $c$

$$
\left(17 c^{2}+(22 a-56 \bar{c}) c+5 a^{2}-32 a \bar{c}+44 \bar{c}^{2}\right) / 72 b=0
$$

The solutions of this polynomial given in equation (17) are

$$
c_{1}=(2 \bar{c}-a) \text { and } c_{2}=(22 \bar{c}-5 a) / 17
$$

\footnotetext{
${ }^{[5]}$ It turns out that $w$ is actually the classical deadweight loss augmented by A3 as shown geometrically in the section on geometric representation.
} 
The first solution, $c_{1}$ is trivial and is exactly the cost level where the new technology becomes drastic, i.e. the cost level where the incumbent's output is zero (see eq. 9) and the two welfare functions are equal. More importantly, the second solution, $c_{2}$ determines the cost level below which the welfare under the monopoly, $W_{m}$ is higher than that under the duopoly, $W_{d}$. The welfare advantage in the case of the monopolistic market structure over the duopoly is shown as being positive when $c_{1}=(2 * 7-10)=4<c<c_{2}=(22 *$ $7-5 * 10) / 17 \cong 6.12$ in Figure 2 for $c=7, a=10$ and $b=1$. When the cost of the new technology $c$ exceeds 6.12 , then the duopolistic market structure becomes superior from a welfare point of view. Therefore, the total welfare under the monopoly is higher or lower than that under the oligopoly depending on whether $c<c_{2}$ or $c>c_{2}$ respectively. None of these two market structures are uniformly superior to the other from a government regulation perspective. Hence, the implications for government regulation are to allow the monopolist to reign if it introduces a significant technological cost reduction, and to promote the competition if the new cost-saving technology is small.

Figure 3

\section{Welfare Calculations Under the Monopoly and the Duopoly}

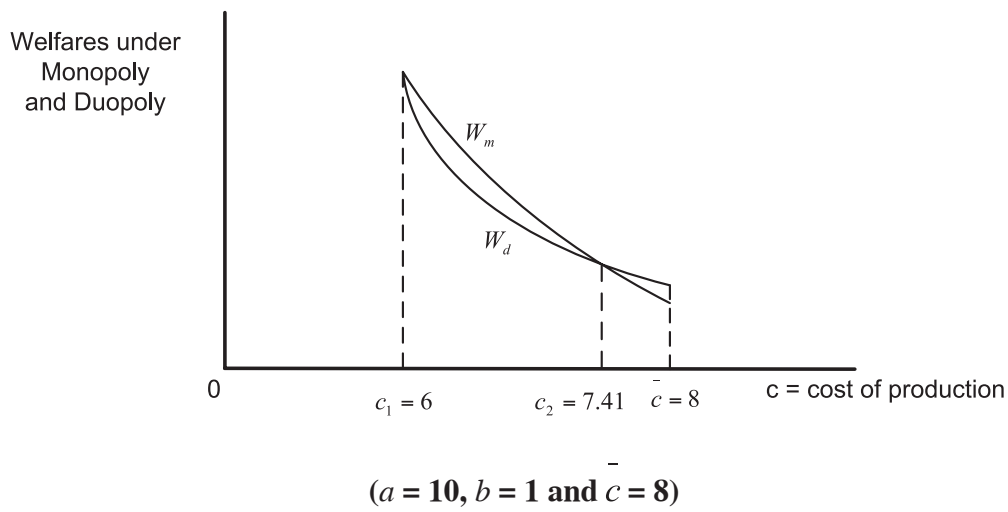

An additional numerical example is given in Figure 3 where the initial cost level $c$ is 8. Then, the critical cost level $c_{2}$, above which the duopolistic market structure becomes better is shown to be 7.41. Moreover, the following general results can be obtained:

a) the welfare when the monopolist innovates is independent of the initial cost level $\bar{c}$ since then it continues its production with the new low-cost technology,

b) the slope of the linear demand curve $b$ does not affect the welfare results,

c) the higher the market bigness parameter $a$ for a given level of initial cost level $\bar{c}$ the lower the critical cost value of the new technology. A larger market can accommodate two firms rather than one, and 
d) the higher the initial cost level $\bar{c}$ for a given level of $a$ the higher the critical cost value of the new technology above which the duopolistic market structure is better from a public policy point of view and therefore there is always a range of small non-drastic innovation where the duopolistic market structure performs better than does the monopolist.

\section{Conclusion}

In this paper, a market environment described by Gilbert and Newberry where the persistence of monopoly versus a challenger threatening the incumbent's profits by entering the market was examined from the welfare point of view. In this case where the strategic moves become important, the private incentives of the monopolist to innovate were already known to be higher compared to those of the new entrant given by the efficiency effect interpreted by Gilbert and Newberry as the total market profits with two firms being necessarily below those of the joint profit maximizing level. However, it was also important to recognize that in the case of the challenger making innovations, the incumbent becomes forced to continue to produce with the higher cost old technology. We showed this extra factor which is an integral part of the efficiency effect geometrically, and noted that this additional factor reinforced why the monopolist may preserve an anticompetitive behavior although some of its inventions might be used while others might be neither employed nor licensed to others.

Moreover, once the consumers' benefits which were found to be higher under the two-firm market structure compared to those under the pure monopolist situation were taken into account, the overall welfare results needed to be investigated further. The major goal of the paper was then to compare the overall welfare results including the private incentives of these two firms given as an efficiency effect in addition to consumers' surpluses when the monopolist may preempt or allow the entrant to share the market. On the one hand, the efficiency effect explained why the private incentives of the monopolist were superior to those of a challenger, and why the monopolist was inclined to preempt. However, on the other hand, there has always been a presumption in the theory of the microeconomics that the monopolies were always uniformly inefficient compared to the competitive markets and that there was a deadweight loss due to the monopolist underproducing and overpricing. In this paper, under the environment given by Gilbert and Newberry, the welfare results are found to depend on the cost of the new technology, i.e. whether the non-drastic innovation is small or big, and hence neither of the two market structures was determined to be uniformly superior to the other. Therefore, the public policy implication is that the monopolist may be allowed to reign if it introduces a significant technological cost reduction, and competition may be promoted if the new cost-saving technology is small.

In Turkey in April 2007, Royal Dutch Shell won a tender to take over some of the distribution of imported natural gas in Turkey from the former monopolist Turkish state company Botaş. The Turkish monopolist which had had contracts to import and distribute annually 25 billion cubic meters ( $\mathrm{bcm}$ ) of gas from Russia, Iran, Algeria and 
Nigeria, then had to transfer 16 bcm of these contracts to Shell. The Russian and Turkish antitrust agencies approved the transfer of the import contracts. In 2007 a new law on market liberalization, dictated Botaş cut its monopolistic ownership of gas contracts to below $20 \%$ of national consumption by the end of 2009. It is also possible that the winds of privatization of state companies may have been responsible for the break-up of the giant Botaş. Our analysis in this paper indicates that this very important political/ economic decision in 2007 was made properly from a microeconomic perspective, if the costs advantage of distribution of gas of the multinational Shell due to its international technology/experience was sufficiently superior compared to the existing monopolist Botaş. Otherwise the law which seems to have considered the privatization as a priority and forced Botaş to abandon its rights of distribution of natural gas may not have improved the overall general economic well-being of both the importers/distributors and the Turkish consumers.

\section{References}

Arrow, K.J. (1962). "Economic Welfare and the Allocation of Resources for Invention," in R. Nelson (ed.) The Rate and Direction of Inventive Activity: Economic and Social Factors: 609-626. (NBER) Princeton University Press.

Behringer, S. (2009). "Entry, Access Pricing, and Welfare in the Telecommunications Industry," Economics Letters, 102(3): 185-188.

Dasgupta, P. and Stiglitz, J.E. (1980a). "Industrial Structure and the Nature of Innovative Activity," The Economic Journal, 90: 266-293.

-----, (1980b). "Uncertainty, Industrial Structure and the Speed of R\&D," Bell Journal of Economics, 11: $1-28$.

Gilbert, R.J. and Newberry, D. (1982). "Preemptive Patenting and the Persistence of Monopoly," American Economic Review, 72(3): 514-526.

------, (1984). "Uncertain Innovation and the Persistence of Monopoly: Comment," American Economic Review, 74(1): 238-242.

Reinganum, J.F. (1983). "Uncertain Innovation and the Persistence of Monopoly," American Economic Review, 73: 741-748.

Scherer, F.M. (1980). Industrial Market Structure and Economic Performance, 2nd ed. Chicago: Rand McNally \& Co.

Singh, V. and Ting, Z. (2008). "Pricing and Market Concentration in Oligopoly Markets," Marketing Science, 27(6): 1020-1035.

Shumpeter, J. (1947). Capitalism, Socialism and Democracy, 2nd ed. London: Allen and Unwin.

Stepanova, A. and Tesoriere, A. (2011). "R \& D with Spillovers: Monopoly versus Noncooperative and Cooperative Duopoloy," Manchester School, 79(1): 125-244.

Tirole, J. (2000) The Theory of Industrial Organization. Cambridge: The MIT Press.

Varian, H.R. (1978). Microeconomic Analysis. New York: W.W. Norton and Company. 